\begin{tabular}{r|l|l|l}
$\begin{array}{r}\text { Case Reports in } \\
\text { Gastroenterology }\end{array}$ & $\begin{array}{l}\text { Case Rep Gastroenterol 2010;4:304-306 } \\
\text { DOl: 10.1159/000320591 }\end{array}$ & $\begin{array}{l}\text { Published online: } \\
\text { September 4, 2010 }\end{array}$ & $\begin{array}{l}\text { O 2010 S. Karger AG, Basel } \\
\text { ISSN 1662-0631 } \\
\text { www.karger.com/crg }\end{array}$ \\
\hline
\end{tabular}

\title{
Recurrent Acute Pancreatitis and Therapy for Ulcerative Colitis
}

\author{
Jean Louis Frossard ${ }^{\mathrm{a}} \quad$ Christian Felley ${ }^{\mathrm{b}} \quad$ Pierre Michetti $^{\mathrm{b}}$ \\ aService of Gastroenterology, Geneva University Hospital, Geneva, and 'bervice of \\ Gastroenterology, Lausanne University Hospital, Lausanne, Switzerland
}

\section{Key Words}

Acute pancreatitis - Cystic fibrosis conductance regulator $\cdot$ Inflammatory bowel disease

\begin{abstract}
Drugs are a rare cause of pancreatitis. Whereas some drugs are well known to induce an attack of pancreatitis, some people may be more prone to develop pancreatitis because of personal susceptibility. We describe a recurrent case of acute pancreatitis after administration of several drugs in a patient with intestinal inflammatory bowel disease that needed to be treated with subsequent antiinflammatory agents. Genetic mutation in the CFTR gene was found in the patient that led us to postulate that CFTR was a trigger for drug-induced acute pancreatitis. In conclusion, genetic analysis should be advised in case of recurrent pancreatitis in patient with intestinal inflammatory bowel disease.
\end{abstract}

\section{Introduction}

Acute pancreatitis is an inflammatory process which occurs in a normal organ and which is diagnosed mainly by acute abdominal pain associated with a concomitant rise of serum amylase and lipase concentrations [1]. Once the diagnosis of acute pancreatitis is confirmed, the cause of the disease must be carefully examined. There is an extensive number of etiologies of acute pancreatitis and in $75-85 \%$ of patients the cause is easily identified. In western countries, gallstone migration along the common bile duct is the most frequent cause of acute pancreatitis before alcohol abuse [2, 3]. Hypertriglyceridemia, hypercalcemia, drugs and pancreatic cancer are other common causes of acute pancreatitis whereas other causes are uncommon, situational, or subject to ongoing controversy such as pancreas divisum or sphincter of Oddi dysfunction [3]. After a complete biological and clinical investigation, $20-30 \%$ of acute pancreatitis cases have no identifiable cause and those patients are often referred to as idiopathic pancreatitis [4]. However, this rate might decrease with recent advances in the understanding of the genetic or autoimmune mechanisms underlying acute pancreatitis. 


\begin{tabular}{r|l|l|l}
$\begin{array}{r}\text { Case Reports in } \\
\text { Gastruanteriology }\end{array}$ & $\begin{array}{l}\text { Case Rep Gastroenterol 2010;4:304-306 } \\
\text { DOI: 10.1159/000320591 }\end{array}$ & $\begin{array}{l}\text { Published online: } \\
\text { September 4, 2010 }\end{array}$ & $\begin{array}{l}\text { O 2010 S. Karger AG, Basel } \\
\text { ISSN 1662-0631 } \\
\text { www.karger.com/crg }\end{array}$ \\
\hline
\end{tabular}

Recently, mutations of the cationic trypsinogen gene (PRSS1), serine protease inhibitor Kazal type 1 (SPINK1) and cystic fibrosis transmembrane conductance regulator (CFTR) genes have been involved in idiopathic recurrent acute pancreatitis and chronic pancreatitis [5]. In pancreatic duct cells, the cystic fibrosis conductance regulator (CFTR) controls chloride and bicarbonate fluxes and consequently pancreatic fluid secretion. Since Sarles et al. [6] described acute pancreatitis with hyper-gamma-globulinemia in 1965, pancreatitis has also been associated with Sjögren syndrome, primary sclerosing cholangitis, or primary biliary cirrhosis.

We here report the case of a young male patient suffering from ulcerative colitis and presenting with recurrent acute episodes of pancreatitis, each of them strongly associated with the introduction of new antiulcerative colitis therapy. Although each episode of pancreatitis was drug-induced, we also found that pancreatitis was associated with a coincidental CFTR mutation that increases the likelihood of pancreatitis in the presence of additional deleterious factors.

\section{Case Report}

A 47-year-old man without any past medical history was diagnosed with ulcerative colitis based on endoscopy and colonic histology. Three weeks after mesalazine and prednisone therapy he presented a first episode of pancreatitis (fig. 1). There was no other medication, no alcohol or tobacco use and no familial history of pancreatic diseases. Calcium and serum triglyceride concentrations as well as liver enzymes were normal. Cholangio-MRI was normal. Mumps serology confirmed previous disease. Two weeks after mesalazine withdrawal, the patient presented a relapse of bloody diarrhea. A new colonoscopy was performed and confirmed a severe form of ulcerative colitis. Intravenous steroids and azathioprine were introduced, but 10 days after the patient presented a recurrent attack of pancreatitis. After 4 weeks of prednisone alone, weekly methotrexate injection was started but followed 3 months after by a third episode of pancreatitis. The absence of a known risk factor for chronic pancreatitis urged us to realize genetic testing. Genetic testing revealed the presence of the CFTR mutation, W1282X, that is known to increase the risk of chronic pancreatitis and idiopathic pancreatitis [7]. The stop of methotrexate was accompanied 3 weeks after by a relapse of colitis treated by infliximab. This treatment was followed by a fourth episode of pancreatitis 2 weeks after its introduction.

\section{Discussion}

The original feature of this case consists in recurrent pancreatitis occurring after the subsequent introduction of four dissimilar drugs used in ulcerative colitis. This case may provide a reasonable explanation for drug-induced pancreatitis.

Personal history, clinical symptoms and laboratory tests may help identify the etiologies of acute pancreatitis, but $15-25 \%$ of cases remain of unknown origin. Drugs induce acute pancreatitis in $1.4-2 \%$ of cases [3]. A recent review classified $\geq 80$ drugs in three categories according to the number of case reports published. Whereas no death has occurred with mesalazine, some have been reported with azathioprine. Azathioprine and mercaptopurine are associated with pancreatitis in 3-15\% of patients that usually resolves upon drug cessation [3]. Methotrexate has been reported in two cases, one of them died. In the current case, the colitis severity required infliximab infusion, a compound also known to induce acute pancreatitis in rare cases.

Recently, genetic mutations have been described in association with pancreatic diseases. CFTR mutations are involved in a variety of clinical conditions other than cystic 


\begin{tabular}{r|l|l|l}
$\begin{array}{r}\text { Case Reports in } \\
\text { Gastruanteriology }\end{array}$ & $\begin{array}{l}\text { Case Rep Gastroenterol 2010;4:304-306 } \\
\text { DOI: 10.1159/000320591 }\end{array}$ & $\begin{array}{l}\text { Published online: } \\
\text { September 4, 2010 }\end{array}$ & $\begin{array}{l}\text { O 2010 S. Karger AG, Basel } \\
\text { ISSN 1662-0631 } \\
\text { www.karger.com/crg }\end{array}$ \\
\hline
\end{tabular}

fibrosis, including chronic bronchitis as well as chronic and idiopathic pancreatitis. CFTR mutations may render some particular patients more susceptible to pancreatitis in the presence of other insults to the pancreas. Indeed, mutations in CFTR may disturb the subtle balance between proteases and their inhibitors by intrapancreatic acidification or by a defective apical trafficking of zymogen granules that might facilitate the intrapancreatic activation of digestive enzymes. Felley et al. [8] already reported that CFTR or SPINK-1 mutation increased the levels of serum pancreatic enzymes and the risk of pancreatitis in HIV patients. In the current case, the patient presented with one known mutation that is associated with an increased risk of pancreatic disease.

In conclusion, we present for the first time a patient suffering from subclinical pancreatic disease that becomes active only when the pancreas is exposed to pancreatotoxic drugs.

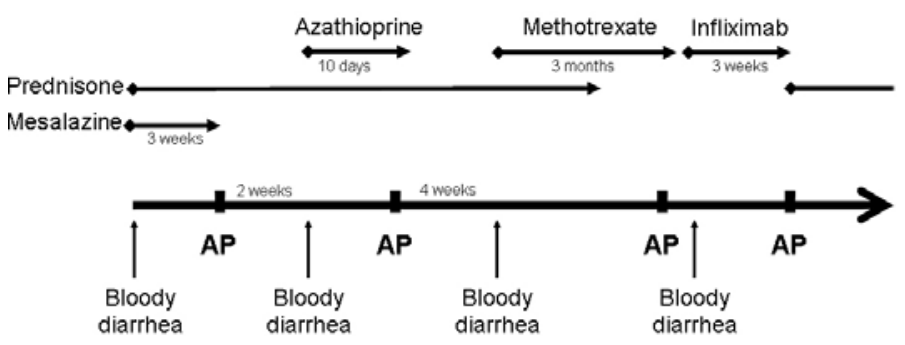

Fig. 1. Patient flowchart (not to scale): time course (horizontal thick arrow) of recurrent attacks of acute pancreatitis (AP) after the introduction of four dissimilar drugs aimed at treating ulcerative colitis. Recurrent bloody diarrhea followed each drug withdrawal (vertical arrows). Thin arrows indicate the start and end of each treatment.

\section{References}

1 Steinberg W, Tenner S: Acute pancreatitis. N Engl J Med 1994;330:1198-1210.

2 Lankish P: Epidemiology of acute pancreatitis; in Buchler MW, Uhl W, Friess H, Malfertheiner P (eds): Acute Pancreatitis: Novel Concepts in Biology and Therapy. Berlin, Blackwell Science, 1999, pp 145-153.

$>3$ Frossard J, Steer M, Pastor C: Acute pancreatitis. Lancet 2008;371:143-152.

4 Frossard JL, et al: Usefulness of endoscopic ultrasonography in patients with 'idiopathic' acute pancreatitis. Am J Med 2000;109:196-200.

5 Whitcomb DC, et al: Third international symposium on inherited diseases of the pancreas. Pancreatology 2001;1:423-431.

6 Sarles H, et al: Observations on 205 confirmed cases of acute pancreatitis, recurring pancreatitis, and chronic pancreatitis. Gut 1965;6:545-559.

7 Frulloni L, et al: Natural history of pancreatitis associated with cystic fibrosis gene mutations. Dig Liver Dis 2003;35:179-185.

8 Felley C, et al: The role of CFTR and SPINK-1 mutations in pancreatic disorders in HIV-positive patients: a case-control study. AIDS 2004;18:1521-1527. 